\title{
The bathymetric distribution of the digenean parasites of deep-sea fishes
}

\author{
Rodney A. Bray \\ Department of Zoology, The Natural History Museum, Cromwell Road, London SW7 5BD, UK
}

Key words: deep sea, bathymetry, Digenea, Lepocreadiidae, Fellodistomidae, Derogenidae, Hemiuridae

\begin{abstract}
The bathymetric range of 149 digenean species recorded deeper than $200 \mathrm{~m}$, the approximate depth of the continental shelf/slope break, are presented in graphical form. It is found that only representatives of the four families Lepocreadiidae, Fellodistomidae, Derogenidae and Hemiuridae reach to abyssal regions $(>4,000 \mathrm{~m})$. Three other families, the Lecithasteridae, Zoogonidae and Opecoelidae, have truly deep-water forms reaching deeper than 3,000 m. Bathymetric data are available for the Acanthocolpidae, Accacoeliidae, Bucephalidae, Cryptogonimidae, Faustulidae, Gorgoderidae, Monorchiidae and Sanguinicolidae showing that they reach deeper than $200 \mathrm{~m}$. No bathymetric data are available for the members of the Bivesiculidae and Hirudinellidae which are reported from deep-sea hosts. These results indicate that only seventeen out of the 150 or so digenean families are reported in the deep sea.
\end{abstract}

Study of the digenean parasites of deep-sea fishes has been spasmodic and scattered. If, as Ronald O'Dor, chief scientist for the 'Census of Marine Life', is reported to have said (Henderson 2003), 'There's more than 99.9 per cent of the ocean that has not been sampled', then the proportion of the deep sea sampled must be considered even lower. As Henderson's (2003) article pointed out, over 1,700 new marine plants or animals are identified each year, yet, in all only about 219 species out of some 18,000 known species of digeneans have been reported in fishes which might be construed as inhabiting the deep sea. Even less is known about the bathymetric distribution of digeneans. We do know that the deep sea harbours its own fauna, and we have some idea of the pressures (metaphorical and physical) exerted on this fauna (Tyler 1995).

The definition of the deep sea used here is the area of water below the continental shelf/slope break, i.e. the point where the gradually inclined shelf gives way to the steeply inclined slope. In most parts of the world this is at a depth of about $200 \mathrm{~m}$. The bottom drops away to the abyssal plain at 4,000 to $6,000 \mathrm{~m}$, with occasional trenches reaching deeper than $11,000 \mathrm{~m}$. The hypsographic curve of the World Oceans and continents reproduced by Merrett and Haedrich (1997) shows that over $50 \%$ of the earth's surface is covered with water deeper than $3,000 \mathrm{~m}$.

\section{DATABASE}

Bray et al. (1999) described a database of published records of deep-sea digeneans. This has now been expanded to 954 host-parasite records and 219 species and is used as the source of data for the analysis discussed here. Only 479 of these records include data on the depths at which the fish hosts were captured. The de- lineation of deep-sea records in the context of the database was based on the depth data greater than $200 \mathrm{~m}$, when given, but if these data were not available, the species of host was used as an indicator that the record was likely to be from the deep sea. Weitzman (1997) summarised the fish groups associated with the deep sea. The database is so small that it is clear that any generalisations must be made with caution and are provisional at best.

\section{RESULTS}

The 479 records of depth data refer to 149 species of digeneans and their reported depth profiles are illustrated in Figs. 1-4. This type of diagram to illustrate bathymetric ranges has become almost a convention in fish studies (e.g. see Merrett and Haedrich 1997), but has not been widely used in other groups, although a less structured version was used by Bray (1995) to illustrate the depth range of digeneans from macrourid fishes.

Only four families have species reaching below 4,000 $\mathrm{m}$ and can be said to inhabit the abyssal regions (Derogenidae, Fellodistomidae, Hemiuridae and Lepocreadiidae). Three further families reach below 3,000 m (Lecithasteridae, Opecoelidae and Zoogonidae), one below 2,000 $\mathrm{m}$ (Gorgoderidae) and three just below 1,000 m (Acanthocolpidae, Accacoeliidae and Sanguinicolidae). Four further families reach below the shelf break at $200 \mathrm{~m}$ (Bucephalidae, Cryptogonimidae, Faustulidae and Monorchiidae). Two further families include species reported from deep-sea fishes, but with no detailed bathymetric data (Bivesiculidae and Hirudinellidae). Therefore, 17 families are reported from

This paper was presented at the 6th International Symposium on Fish Parasites in Bloemfontein, South Africa, 22-26 September 2003. 
the deep sea. This is a rather small proportion of the about 150 digenean families, over $50 \%$ of which occur in fishes (Gibson and Bray 1994). This figure was quoted as 18 by Bray et al. (1999), but the Bunocotylidae is now widely considered a subfamily of the Hemiuridae (León-Règagnon et al. 1998, Gibson 2002, Olson et al. 2003).

Undescribed digeneans have been found in fishes from hydrothermal vents at 3,000 $\mathrm{m}$ and 2,600 $\mathrm{m}$ depth (De Buron and Morand 2004).

Each family is briefly discussed below.

Lepocreadiidae Odhner, 1905

Fig. 1

Two subfamilies are represented in deep-waters, the Lepocreadiinae Odhner, 1905 and the Lepidapedinae Yamaguti, 1958. Lepidapedines are the most frequently reported of all digeneans in abyssal regions, with three species recorded. One, Profundivermis intercalarias Bray et Gibson, 1991, is the only species so far known only from the abyssal plain (Bray and Gibson 1991, Bray et al. 1999). Lepidapedon discoveryi Bray et Gibson, 1995 and L. beveridgei Campbell et Bray, 1993 have much greater bathymetric ranges, reflecting the range of their principal host, Coryphaenoides (Nematonurus) armatus. There is a group of eight Lepidapedon Stafford, 1904 species that reach to about 3,000 m, and two further species of this genus are found deeper than other lepocreadiids. It has been postulated that Lepidapedon has radiated predominantly in deep-water (Bray et al. 1999). Paralepidapedon Shimazu et Shimura, 1984 (two species) and Neolepidapedon Manter, 1954 (one species) are the only other genera found deeper than $1,000 \mathrm{~m}$. The only lepocreadiine species in Fig. 1, Prodistomum priedei Bray et Merrett, 1998, is, however, reported to $985 \mathrm{~m}$ (Bray and Merrett 1998). This parasite appears to have migrated into deep water in parallel with its perciform host. The Perciformes, an enormous shallow-water group, has relatively few deepsea representatives (Weitzman 1997). Two other lepidapedine genera, Postlepidapedon Zdzitowiecki, 1993 and Gibsonia Gaevskaya et Rodyuk, 1988, have representatives that inhabit waters below the shelf break.

Fellodistomidae Nicoll, 1909

Fig. 2

Nineteen species are included in Fig. 2, but only one (Steringophorus thulini Bray et Gibson, 1980) reaches to abyssal depths. S. thulini apparently has a large depth range, specimens from 1,745-1,760 $\mathrm{m}$ and 4,100 $\mathrm{m}$ having near identical partial nuclear LSU rDNA (933 bp, just a single base difference), but different partial mitochondrial ND1 sequences (473 bp, 32 base differences) (Bray et al. 1999). As the LSU rDNA sequences were so similar, it may be that the ND1 differences (although not all are silent substitutions) are population differences rather than indicators of speciation, or possibly pseudogenes have been sequenced (D.T.J. Littlewood, pers. comm.). Steringophorus Odhner, 1905 is, like Lepidapedon, thought to have radiated predominantly in deep water (Bray et al. 1999) and is the largest

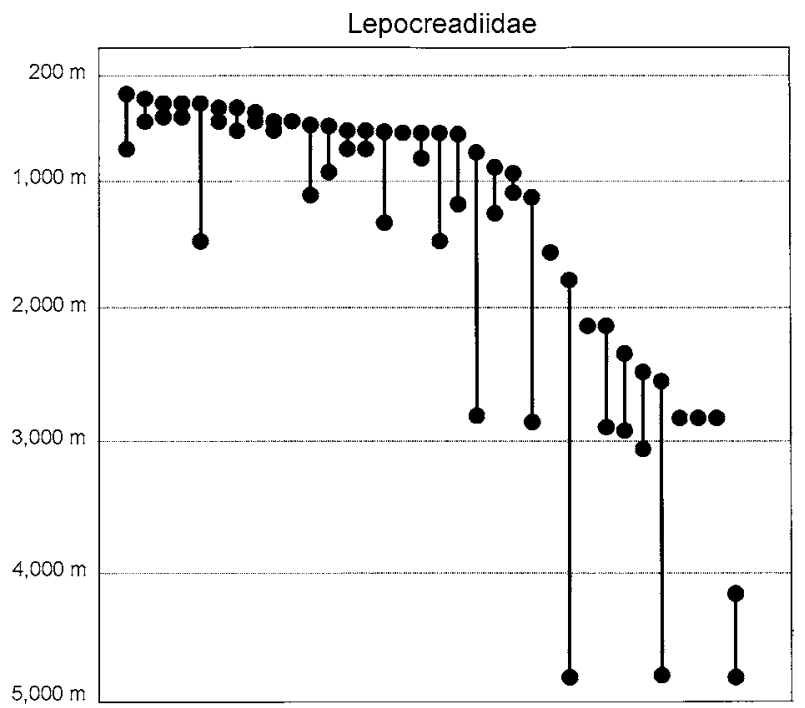

Fig. 1. Individual bathymetric ranges of digeneans. Species listed below in sequence from the left. Lepocreadiidae: Lepidapedon merretti Campbell et Bray, 1993, Paralepidapedon lepidum (Gaevskaya et Rodyuk, 1988), Lepidapedon caribbaei Blend, Dronen et Armstrong, 2000, L. longivesicula Blend, Dronen et Armstrong, 2000, L. arlenae Bray et Gibson, 1995, L. lebouri Manter, 1934, L. mexicanesis Blend, Dronen et Armstrong, 2000, Gibsonia borealis Campbell, 1992, Lepidapedon blairi Bray et Jones, 1993, Gibsonia hastata Gaevskaya et Rodyuk, 1988, Lepidapedon mariannae Bray et Gibson, 1995, Prodistomum priedei Bray et Merrett, 1998, Lepidapedon desotoensis Blend, Dronen et Armstrong, 2000, L. zaniophori Blend, Dronen et Armstrong, 2000, L. desclersae Bray et Gibson, 1995, L. ninae Zdzitowiecki et Cielecka, 1997, Postlepidapedon opisthobifurcatus (Zdzitowiecki, 1990), Paralepidapedon awii Zdzitowiecki et Cielecka, 1997, Lepidapedon nezumiatus Blend, Dronen et Armstrong, 2000, L. abyssensis McCauley, 1968, Paralepidapedon williamsi Bray et Gibson, 1988, Neolepidapedon smithi Bray et Gibson, 1989, Lepidapedon sommervillae Bray et Gibson, 1995, L. brayi Zdzitowiecki et Cielecka, 1997, L. beveridgei Campbell et Bray, 1993, L. antimorae McCauley, 1968, L. yaquina McCauley, 1968, L. gaevskayae Campbell et Bray, 1993, L. zubchenkoi Campbell et Bray, 1993, L. discoveryi Bray et Gibson, 1995, L. cascadensis McCauley, 1968, L. filiformis McCauley, 1968, L. oregonensis McCauley, 1968, Profundivermis intercalarius Bray et Gibson, 1991.

fellodistomid genus found in deep water, with nine species in Fig. 2. The second deepest recorded fellodistome is Hypertrema ambovatum Manter, 1960 (to 3,000 m), slightly deeper than Steringophorus haedrichi Bray et Campbell, 1995 (to 2,949 m). S. furciger (Olsson, 1868) is unusual in that it is reported from shallow water (often in flatfishes) down to $2,609 \mathrm{~m}$, giving rise to the suspicion that more than one species is known under this name. Almost as deep, but with a smaller range, is Olssonium turneri Bray et Gibson, 1980, which reaches to 2,570 m. Megenteron crassum Manter, 1934 reaches to $1,730 \mathrm{~m}$ and Prudhoeus nicholsi Bray et Gibson, 1980 to 1,320 m. Megenteron Manter, 1934, Lissoloma Manter, 1934 and Lomasoma Manter, 1935, which are 


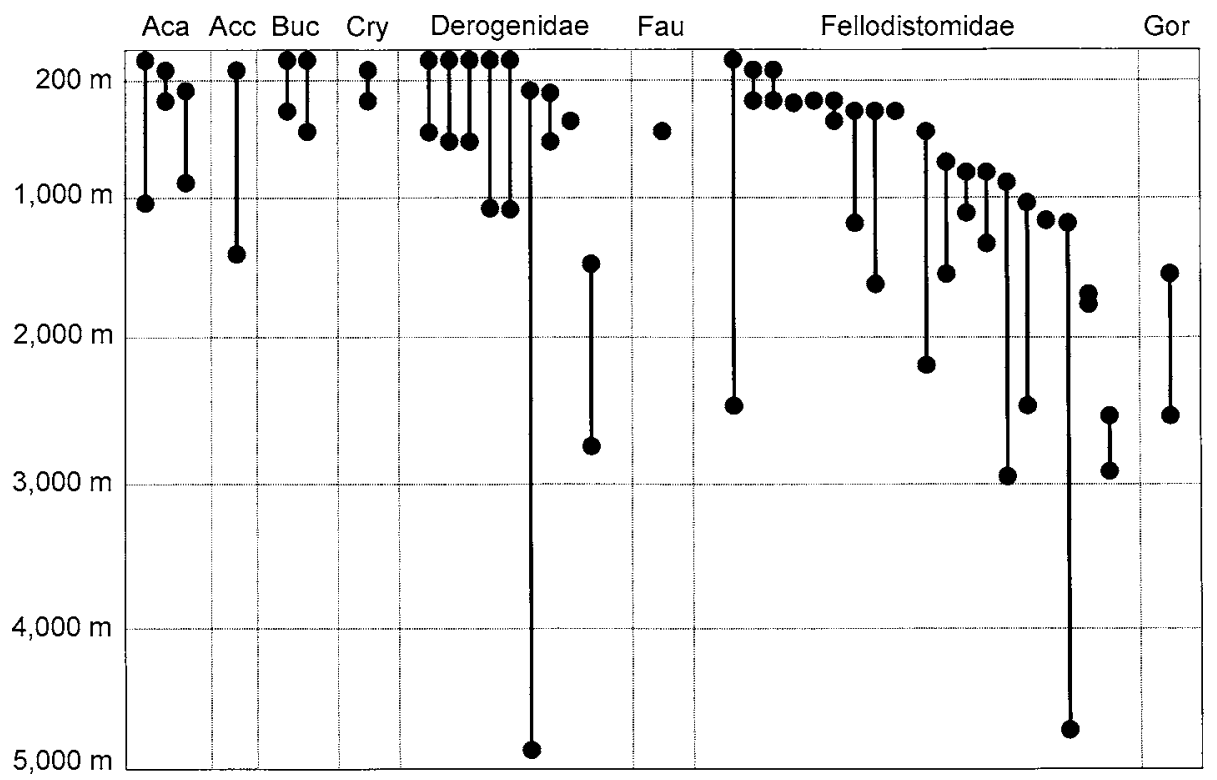

Fig. 2. Individual bathymetric ranges of digeneans. Species listed below in sequence from the left. Acanthocolpidae: Neophasis oculatus (Levinsen, 1881), Stephanostomum lineatum Manter, 1934, Spinoplagioporus minutus (Polyansky, 1952). Accacoeliidae: Paraccacladium jamiesoni Bray et Gibson, 1977. Bucephalidae: Prosorhynchus squamatus Odhner, 1905, Prosorhynchoides gracilescens (Rudolphi, 1819). Cryptogonimidae: Metadena brotulae (Manter, 1934). Derogenidae: Progonus muelleri (Levinsen, 1881), Gonocerca crassa Manter, 1934, Hemiperina nicolli Manter, 1934, Derogenes varicus (Müller, 1784), D. macrostoma Yamaguti, 1938, Gonocerca phycidis Manter, 1925, G. japonica Toman, 1973, G. oshoro Shimazu, 1970, G. oregonensis McCauley, Pequegnat et Brownell, 1970. Faustulidae: Echinobreviceca coelorhynchae Dronen, Blend et McEachran, 1994. Fellodistomidae: Steringophorus furciger (Olsson, 1868), Lissoloma brotulae Manter, 1934, Lomasoma monolenei (Manter, 1934), L. gracilis (Manter, 1934), Steringophorus profundus Manter, 1934, Lomasoma wardi (Manter, 1934), Steringophorus blackeri Bray, 1973, Megenteron crassum Manter, 1934, Steringophorus magnus Manter, 1934, S. pritchardae (Campbell, 1975), S. dorsolineatum (Reimer, 1985), Megenteron manteri Harris et Dronen, 1999, Prudhoeus nicholsi Bray et Gibson, 1980, Hypertrema ambovatum Manter, 1960, Olssonium turneri Bray et Gibson, 1980, Benthotrema plenum Manter, 1934, Steringophorus thulini Bray et Gibson, 1980, S. margolisi Bray, 1995, S. haedrichi Bray et Campbell, 1995. Gorgoderidae: Degeneria halosauri (Bell, 1887).

restricted to the upper slope, are morphologically close to Steringophorus (see Bray 2002) and may not ultimately be considered distinct.

Hemiuridae Looss, 1899

Fig. 3

Nineteen species are shown in the figure. One species, Glomericirrus macrouri (Gaevskaya, 1975), reaches into abyssal regions, being reported down to 4,057 $\mathrm{m}$ (Bray et al. 1999) and as having a large depth range. Merlucciotrema praeclarum (Manter, 1934) is the next deepest at 2,784 m, with a group of Dinosoma Manter, 1934 species reaching between 1,000 and about $2,000 \mathrm{~m}$. Two other Dinosoma species are found around $500-600 \mathrm{~m}$. The remainder of the hemiurids in Fig. 3 are probably shallow-water forms which occasionally encroach into deeper water. This is particularly evident with the well-known species Hemiurus communis Odhner, 1905, H. levinseni Odhner, 1905, Genolinea laticauda Manter, 1925, Lecithochirium rufoviride (Rudolphi, 1819) and Brachyphallus crenatus (Rudolphi, 1802), and it is quite surprising that the first three are reported almost to or deeper than $1,000 \mathrm{~m}(980 \mathrm{~m}$, $1,030 \mathrm{~m}$ and $1,080 \mathrm{~m}$, respectively).
Derogenidae Nicoll, 1910

Fig. 2

Nine species are reported, one of which, Gonocerca phycidis Manter, 1925, reaches into abyssal regions $(4,847 \mathrm{~m})$ (Bray et al. 1999). Apart from other species of Gonocerca Manter, 1925 (G. oregonensis McCauley, Pequegnat et Brownell, 1970 is reported to $2,850 \mathrm{~m}$ ), the derogenids reported here are shallow-water forms encroaching into deeper water. This is clearly the case for very common shallow-water form Derogenes varicus (Müller, 1784) and also for Hemipera nicolli (Manter, 1934) and Progonus muelleri (Levinsen, 1881). The deeper records of D. varicus are, as Manter (1966) pointed out, from warmer waters and that it "probably has a continuous, world-wide distribution in deeper waters', an example of 'equatorial submergence' (Ekman 1953). Gage and Tyler (1991) pointed out that the idea of deep-sea colonisation from polar seas is 'deeply embedded, but still largely untested' in the literature. Bray et al. (1999) found great similarity between Antarctic and deep-sea digeneans, indicating that temperature was a determinant of the deep-sea fauna, but they also reckoned that much radiation had occurred in 


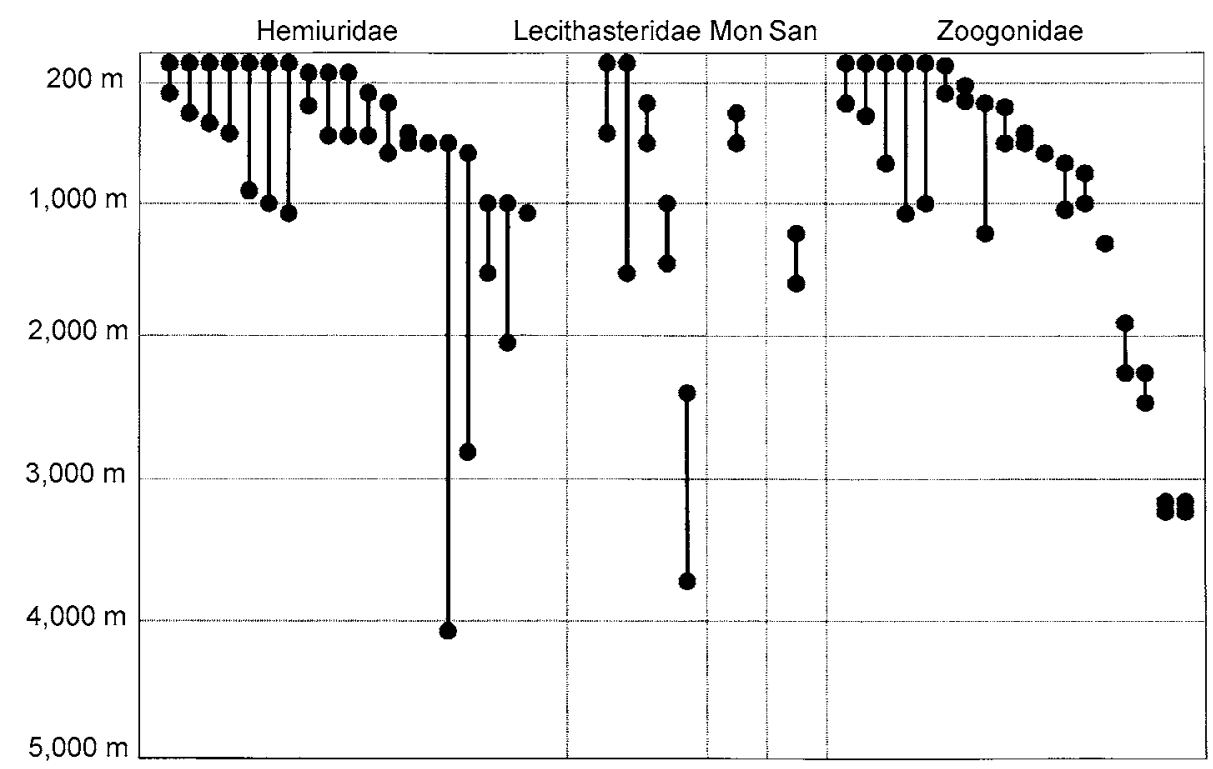

Fig. 3. Individual bathymetric ranges of digeneans. Species listed below in sequence from the left. Hemiuridae: Dinosoma tortum Yamaguti, 1938, Dissosaccus laevis (Linton, 1898), Lecithochirium rufoviride (Rudolphi, 1819), Brachyphallus crenatus (Rudolphi, 1802), Hemiurus communis Odhner, 1905, Genolinea laticauda Manter, 1925, Hemiurus levinseni Odhner, 1905, Lethadena profunda (Manter, 1934), Dinosoma rubrum Manter, 1934, Lecithochirium floridense (Manter, 1934), Adinosoma robustum (Manter, 1934), Lecithochirium whitei Zdzitowiecki, 1994, Dinosoma synaphobranchi Yamaguti, 1938, Dinosoma triangulata Campbell et Munroe, 1977, Glomericirrus macrouri (Gaevskaya, 1975), Merlucciotrema praeclarum (Manter, 1934), Dinosoma pectoralis McCauley et Pequegnat, 1968, Dinosoma oregonensis McCauley et Pequegnat, 1968, Dinosoma ventrovesicularis Gibson et Bray, 1986. Lecithasteridae: Lecithaster gibbosus (Rudolphi, 1802), Lecithophyllum botryophorum (Olsson, 1868), Aponurus intermedius Manter, 1934, Lecithophyllum irelandeum Orias, Noble et Alderson, 1978, Lecithophyllum euzeti Gibson et Bray, 2003. Monorchiidae: Bathymonorchis polyipni (Reimer, 1985). Sanguinicolidae: Aporocotyle simplex Odhner, 1900. Zoogonidae: Zoogonoides viviparus (Olsson, 1868), Lepidophyllum steenstrupi Odhner, 1902, Pseudozoogonoides subaequiporus (Odhner, 1911), Steganoderma formosum Stafford, 1904, Lepidophyllum appyi Bray et Gibson, 1986, Pseudopalaeorchis aberratus Reimer, 1985, Brachyenteron peristedioni Manter, 1934, Proctophantastes abyssorum Odhner, 1911, Brachyenteron pycnorganum (Rees, 1953), Steganodermatoides notocanthi Korotaeva, 1994, Koiea notacanthi Bray et Campbell, 1995, Steganodermatoides maceri Bray et Gibson, 1986, Panopula bridgeri Bray et Gibson, 1986, Brachyenteron campbelli Bray et Gibson, 1986, Steganodermatoides agassizi (Campbell, 1975), Brachyenteron rissoanum Bray et Campbell, 1995, Neosteganoderma gillissi Overstreet et Pritchard, 1977, Panopula cavernossa Overstreet et Pritchard, 1977.

the deep sea. It is apparent, however, that in the deep water of cold higher latitudes the niche of $D$. varicus is taken by $G$. phycidis.

Opecoelidae Ozaki, 1925

Fig. 4

Thirty-four species of this enormous family occur in deep-water, but none reaches to the abyss and a high proportion appear to be shallow-water forms encroaching into deep water. The deepest species Neolebouria merretti Gibson et Bray, 1982 is found down to 3,311 m (Gibson and Bray 1982). Four further species reach below 2,000 m (Podocotyle schistotesticulata Bray et Campbell, 1996, P. harrisae Bray et Campbell, 1996, Gaevskajatrema halosauropsi Bray et Campbell, 1996 and Allopodocotyle margolisi Gibson, 1995) and four to $1,000 \mathrm{~m}$ or deeper (Bathycreadium flexicollis Kabata, 1961, Helicometra robinsonorum Overstreet et Martin, 1974, Tellervotrema armstrongi Gibson et Bray, 1982 and Stenakron vetustum Stafford, 1904). S. vetustum is a relatively shallow-water form, but can apparently reach below 1,000 m (Boje et al. 1997). Most other opecoelids in Fig. 4 are poorly known species from middepths be- tween 200 and $1,000 \mathrm{~m}$ or shallow-water forms encroaching into similar middepths. Species of Bathycreadium Kabata, 1961 appear to be restricted to upper slope waters.

Zoogonidae Odhner, 1902

Fig. 3

Two species (Neosteganoderma gillisii Overstreet et Pritchard, 1977 and Panopula cavernossa Overstreet et Pritchard, 1977) reach into water deeper than 3,000 m (Overstreet and Pritchard 1977) and two (Steganodermatoides agassizi (Campbell, 1975), Brachyenteron rissoanum Bray et Campbell, 1995) deeper than 2,000 m. Six others reach below $1,000 \mathrm{~m}$, four of which (Proctophantastes abyssorum Odhner, 1911, S. maceri Bray et Gibson, 1986, Panopula bridgeri Bray et Gibson, 1986, B. campbelli Bray et Gibson, 1986) do not reach onto the continental shelf. As with other families there are a group of forms which are mainly shelf dwellers, but are occasionally taken into deep water and, in the case of Steganoderma formosum Stafford, 1904 and Lepidophyllum appyi Bray et Gibson, 1986, deeper than $1,000 \mathrm{~m}$. 


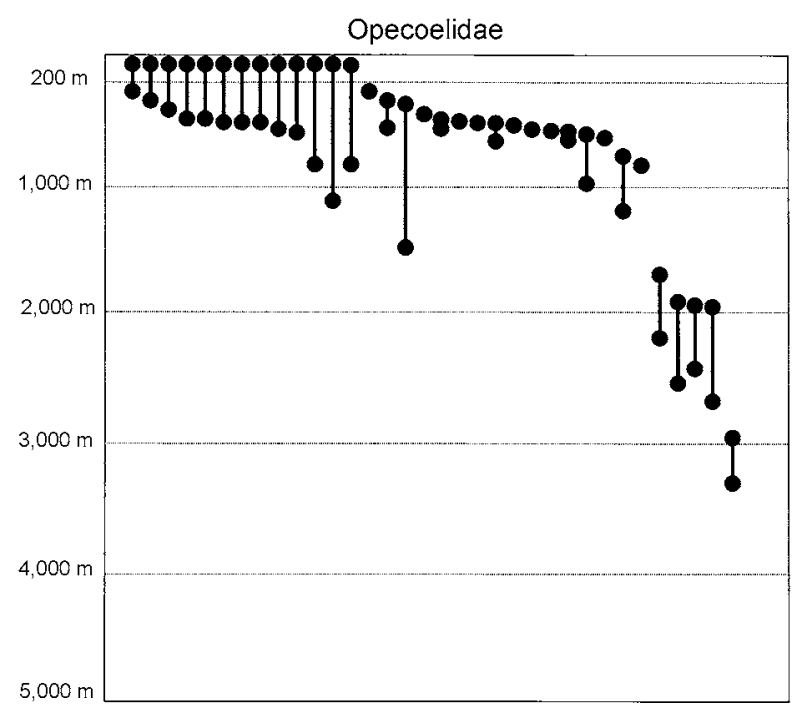

Fig. 4. Individual bathymetric ranges of digeneans. Species listed below in sequence from the left. Opecoelidae: Macvicaria pacifica (Yamaguti, 1938), Opecoeloides fimbriatus (Linton, 1905), Neolebouria acanthogobii (Yamaguti, 1951), Pseudopecoeloides boops Yamaguti, 1970, P. carangis (Yamaguti, 1938), P. akule Yamaguti, 1970, Opegaster tamori Yamaguti, 1938, Helicometra plovmornini Issaischikov, 1928, Pseudopecoelus japonicus (Yamaguti, 1938), P. vulgaris (Manter, 1934), Neolebouria lobata (Yamaguti, 1934), Stenakron vetustum Stafford, 1904, Anomalotrema koiae Gibson et Bray, 1984, Prolabria monocentris Reimer, 1987, Bathycreadium biscayense Bray, 1973, B. flexicollis Kabata, 1961, Opecoelina helicoleni Manter, 1934, Mesocreadium hoplichthidis Reimer, 1987, Eurycreadium vitellosum Manter, 1934, Opecoelina scorpaenae Manter, 1934, Podocotyle pearsei Manter, 1934, Labracetabulum gephyroberici Reimer, 1987, Buticulotrema stenauchenus Blend, Dronen et McEachran, 1993, Neolebouria lanceolata (Price, 1934), Plagioporus katadara Kuramochi, 2001, Tellervotrema armstrongi Gibson et Bray, 1982, Opegaster caulopsettae Manter, 1954, Helicometra robinsorum Overstreet et Martin, 1974, Macvicaria selachophidii Reimer, 1987, Allopodocotyle margolisi Gibson, 1995, Gaevskajatrema halosauropsi Bray et Campbell, 1996, Podocotyle harrisae Bray et Campbell, 1996, P. schistotesticulata Bray et Campbell, 1996, Neolebouria merretti Gibson et Bray, 1982.

\section{Lecithasteridae Odhner, 1905}

Fig. 3

Recent molecular results indicate this family should probably be included in the Hemiuridae (Cribb et al. 2001, Olson et al. 2003). Only five species have been reported in deep-water, but one (Lecithophyllum euzeti Gibson et Bray, 2003 from notacanthiform eels) reaches almost to 4,000 m (Gibson and Bray 2003) and one ( $L$. irelandeum Orias, Noble et Anderson, 1978 from a bathypelagic melamphaeid) to $1,500 \mathrm{~m}$ (Orias et al. 1978). L. botryophorum (Olsson, 1868) is reported to 1,653 m (new observation, in Alepocephalus bairdii) and is essentially a deep-water parasite, but may occur in relatively shallow water (Køie 2000). This species is unusual in that it uses scaphopods as first intermediate host (Køie et al. 2002). Scaphopods constitute less than
$1 \%$ of the shallow-water mollusc fauna, but in the deep sea this proportion in much increased (Gage and Tyler 1991).

Gorgoderidae Looss, 1899

Fig. 2

One species, Degeneria halosauri (Bell, 1887), is reported in the deep sea to $2,654 \mathrm{~m}$. The first deep-sea digenean described, it is found in the urinary bladder of the halosaurid notacanthiform Halosauropsis macrochir (Bell 1887, Campbell 1977).

Accacoeliidae Odhner, 1911

Fig. 2

We know of only one genuine deep-sea accacoeliid, Paraccacladium jamiesoni Bray et Gibson, 1977, which is a widespread species found down to $1,400 \mathrm{~m}$ (Zubchenko 1993).

Acanthocolpidae Lühe, 1906

Fig. 2

This large family probably has many species that reach past the shelf break, but only three are reported, one of which, Neophasis oculatus (Levinsen, 1881), is reported to $1,030 \mathrm{~m}$ (Køie 2000). Spinoplagioporus minutus (Polyansky, 1952), which reaches to $920 \mathrm{~m}$ (new observation), is unusual in that it parasitizes holocephalans of the genera Chimaera and Hydrolagus.

Bucephalidae Poche, 1907

Fig. 2

This is a large family with only two deep-sea species reported with bathymetric data. Neither is found in very deep water. Prosorhynchoides gracilescens (Rudolphi, 1819) reaches to $727 \mathrm{~m}$ (Køie 2000). An undescribed Bucephalus-like digenean has been reported at high prevalences (up to 100\%) from cold-seep mussels at 538-552 m depth (Powell et al. 1999).

Sanguinicolidae von Graff, 1907

Fig. 3

Zubchenko (1981) reported Aporocotyle simplex Odhner, 1900 from the macrourid Coryphaenoides rupestris off eastern Canada and later (Zubchenko 1993) gave bathymetric data, indicating that it reached to $1,600 \mathrm{~m}$. In view of the high host-specificity of most sanguinicolids, Gibson (1996) suggested that this was a misidentification.

Faustulidae Poche, 1926

Fig. 2

This family has radiated greatly in coral reef fishes, but one species (Echinobreviceca coelorhynchae Dronen, Blend et McEachran, 1994) is known in deep water, being reported in a macrourid to $473 \mathrm{~m}$ (Dronen et al. 1994).

Monorchiidae Odhner, 1911

Fig. 3

Bathymonorchis polyipni (Reimer, 1985) is the only species of this large family reported in deep water, having been found in bathypelagic fishes to $600 \mathrm{~m}$ (Reimer 1985, Bray and Gaevskaya 1993). Digeneans are rarely found in bathypelagic fishes (Noble and Collard 1970, Gartner and Zwerner 1989).

Cryptogonimidae Ward, 1917

Fig. 2

This large family is represented by one species, Metadena brotulae (Manter, 1934), in deep water, but only to $256 \mathrm{~m}$ (Manter 1934). 
Bivesiculidae Yamaguti, 1934

No bathymetric data are available, but Shimazu and Machida (1995) found Bivesicula ostichthydis Shen, 1982 in the ophidiid Brotula multibarbata landed in Japan.

\section{Hirudinellidae Dollfus, 1932}

Parukhin (1976) reported Botulus microporus (Monticelli, 1889) (as B. skrjabini Skrjabin, 1958) from the ovary of the macrourid Coryphaenoides striatura off the eastern coast of southern Africa. This species normally occurs in bathypelagic alepisaurids, particularly Alepisaurus ferox (see Gibson and Bray 1977), which ranges as deep as 1,829 $\mathrm{m}$ (Froese and Pauly 2003). Its site of infection in the macrourid suggests that it may have been a juvenile stage.

\section{CONCLUSIONS}

It is appropriate, again, to stress that the database is small and that a good proportion of the species have only been reported once. It is possible, however, to make a few generalisations. Clearly a relatively few families contain species that have successfully radiated in the really deep sea (below about 3,000 m). The best evidence we have is that only the Lepocreadiidae and Fellodistomidae have species-rich genera in the deeper regions, in particular Lepidapedon and Steringophorus. No genera appear to have radiated, however, solely in the deep sea. In fact, only the currently monotypic Profundivermis is restricted to abyssal depths. On the other hand, most species that reach into abyssal depths have large bathymetric ranges. Gonocerca phycidis, for example, has an enormous range, although it may be that the species as now recognised is a complex of sibling species. Some of the molecular evidence relating to Steringophorus thulini, which also has a large range, may indicate such speciation (see above).

The finding of many mainly shallow-water species reaching well down the continental slope, e.g. Derogenes varicus, Hemiurus levinseni, H. communis and Steganoderma formosum, emphasises the difficulty in delimiting the deep-sea fauna in the shallower regions. No parasite, however, reaches from shelf water into the abyss, with the possible exception of Gonocerca phycidis.

The depth ranges of digeneans are clearly dictated to some extent by the distribution of their definitive hosts and are, presumably, also limited by the intermediate host. The predominant groups of fishes in deep-water are non-perciforms, which certainly has an effect on the digenean families recovered. For example, the huge family Didymozoidae, normally tissue parasites of perciforms has not been reported from the deep sea. Families reliant on herbivorous perciform hosts, such as the haploporids, haplosplanchnids, mesometrids, enenterids or gyliauchenids, have no niche in the deep sea. It is apparent, therefore, that the diversity of digeneans is relatively low in the deep sea, although prevalences and abundances may be high (Campbell et al. 1980).

\section{REFERENCES}

BELL F.J. 1887: Description of a new species of Distomum. Ann. Mag. Nat. Hist., Ser. 5 19: 116-117.

BOJE J., RIGET F., KØIE M. 1997: Helminth parasites as biological tags in population studies of Greenland halibut (Reinhardtius hippoglossoides (Walbaum)), in north-west Atlantic. ICES J. Mar. Sci. 54: 886-895.

BRAY R.A. 1995: Annotated checklist of digenean parasites of Macrouridae (Teleostei, Gadiformes). Acta Parasitol. 40: $168-192$.

BRAY R.A. 2002: Family Fellodistomidae Nicoll, 1909. In: D.I. Gibson, A. Jones and R.A. Bray (Eds.), Keys to the Trematoda. Volume 1. CABI Publishing and The Natural History Museum, Wallingford, pp. 261-293.

BRAY R.A., GAEVSKAYA A.V. 1993: Bathymonorchis polyipni (Reimer, 1985) n. g., n. comb. (Digenea: Monorchiidae) from bathypelagic fishes of the eastern midAtlantic Ocean. Syst. Parasitol. 26: 91-95.

BRAY R.A., GIBSON D.I. 1991: The Lepocreadiidae (Digenea) of fishes from the north-east Atlantic: Profundivermis intercalarius $\mathrm{n}$. g., $\mathrm{n}$. sp. from the marine fish Coryphaenoides (Nematonurus) armatus (Hector) (Macrouridae) from the Porcupine Abyssal Plain. Syst. Parasitol. 18: $121-125$.

BRAY R.A., LITTLEWOOD D.T.J., HERNIOU E.A., WILLIAMS B., HENDERSON R.E. 1999: Digenean parasites of deep-sea teleosts: a review and case studies of intrageneric phylogenies. Parasitology 119 (Supplement): S125-S144.

BRAY R.A., MERRETT N.R. 1998: Prodistomum priedei $\mathrm{n}$. sp. (Digenea: Lepocreadiidae) from the deepwater cardinalfish Epigonus telescopus (Perciformes: Epigonidae) in the northern Atlantic Ocean. Syst. Parasitol. 41: 71-77.

CAMPBELL R.A. 1977: Degeneria halosauri (Bell, 1887) gen. et comb. nov. (Digenea: Gorgoderidae) from the deep-sea teleost Halosauropsis macrochir. J. Parasitol. 63: 76-79.

CAMPBELL R.A., HAEDRICH R.L., MUNROE T.A. 1980: Parasitism and ecological relationships among deep-sea benthic fishes. Mar. Biol. 57: 301-313.

CRIBB T.H., BRAY R.A., LITTLEWOOD D.T.J., PICHELIN S., HERNIOU E.A. 2001: The Digenea. In: D.T.J. Littlewood and R.A. Bray (Eds.), Interrelationships of the Platyhelminthes. Taylor \& Francis, London, pp. 168-185.

De BURON I., MORAND S. 2004: Deep-sea hydrothermal vent parasites: why do we not find more? Parasitology 128: $1-6$.

DRONEN N.O., BLEND C.K., McEACHRAN J.D. 1994: Echinobreviceca coelorhynchae n. gen., n. sp. (Echinobrevicecinae n. subf.), a fellodistomid from Coelorhynchus coelorhynchus (Macrouridae) from the Gulf of Mexico. J. Parasitol. 80: 309-311. 
EKMAN S. 1953: Zoogeography of the Sea (English translation, 1967). Sidgwick \& Jackson, London, 417 pp.

FROESE R., PAULY D. 2003: FishBase. World Wide Web electronic publication. www.fishbase.org.

GAGE J.D., TYLER P.A. 1991: Deep-sea Biology. A Natural History of Organisms at the Deep-sea Floor. Cambridge University Press, Cambridge, $504 \mathrm{pp}$.

GARTNER J.V. Jr., ZWERNER D.E. 1989: The parasite faunas of meso- and bathypelagic fishes of Norfolk Submarine Canyon, western North Atlantic. J. Fish. Biol. 34: 79-95.

GIBSON D.I. 1996: Trematoda. In: L. Margolis and Z. Kabata (Eds.), Guide to the Parasites of Fishes of Canada, Part IV. NRC Research Press, Canadian Special Publication of Fisheries and Aquatic Sciences, 124, Ottawa, pp. 1-373.

GIBSON D.I. 2002: Family Hemiuridae Looss, 1899. In: D.I. Gibson, A. Jones and R.A. Bray (Eds.), Keys to the Trematoda. Volume 1. CAB International, Wallingford, pp. 307-340.

GIBSON D.I., BRAY R.A. 1977: The Azygiidae, Hirudinellidae, Ptychogonimidae, Sclerodistomidae and Syncoeliidae of fishes from the north-east Atlantic. Bull. Br. Mus. (Nat. Hist.) (Zool. Ser.) 32: 167-245.

GIBSON D.I., BRAY R.A. 1982: A study and reorganization of Plagioporus Stafford, 1904 (Digenea: Opecoelidae) and related genera, with special reference to forms from European Atlantic waters. J. Nat. Hist. 16: 529-559.

GIBSON D.I., BRAY R.A. 1994: The evolutionary expansion and host-parasite relationships of the Digenea. Int. J. Parasitol. 24: 1213-1226.

GIBSON D.I., BRAY R.A. 2003: Lecithophyllum euzeti n. sp. (Digenea: Lecithasteridae) from notacanthid fishes in the deep-waters of the Porcupine Sea Bight, north-east Atlantic. In: C. Combes and J. Jourdane (Eds.), Taxonomie, Écologie et Évolution des Métazoaires Parasites. Taxonomy, Ecology and Evolution of Metazoan Parasites. (Livre hommage à Louis Euzet). Tome I. Presses Universitaire de Perpignan, Perpignan, pp. 347-358.

HENDERSON M. 2003: How many fish in the seas? 15,304 and counting. In: "The Times", p. 20, Friday October 24, London.

KØIE M. 2000: Metazoan parasites of teleost fishes from Atlantic waters off the Faroe Islands. Ophelia 52: 25-44.

KØIE M., KARLSBAKK E., NYLUND A. 2002: A cystophorous cercaria and metacercaria in Antalis entalis (L.) (Mollusca, Scaphopoda) in Norwegian waters, the larval stage of Lecithophyllum botryophorum (Olsson, 1868) (Digenea, Lecithasteridae). Sarsia 87: 302-311.

LEÓN-RĖGAGNON V., PÉREZ-PONCE de LEÓN G., BROOKS D.R. 1998: Phylogenetic analysis of the Bunocotylinae Dollfus, 1950 (Digenea: Hemiuridae). J. Parasitol. 84: 147-152.
MANTER H.W. 1934: Some digenetic trematodes from deepwater fish of Tortugas, Florida. Pap. Tortugas Lab. 28: 257-345.

MANTER H.W. 1966: Parasites of fishes as biological indicators of recent and ancient conditions. In: J.E. McCauley (Ed.), Host-Parasite Relationships. Oregon State University Press, Oregon, pp. 59-71.

MERRETT N.R., HAEDRICH R.L. 1997: Deep-sea Demersal Fish and Fisheries. Chapman \& Hall, London, 282 pp.

NOBLE E.R., COLLARD S.B. 1970: The parasites of midwater fishes. In: S.F. Snieszko (Ed.), A symposium on diseases of fishes and shellfishes. American Fisheries Society Special Publication, 5, pp. 57-68.

OLSON P.D., CRIBB T.H., TKACH V.V., BRAY R.A., LITTLEWOOD D.T.J. 2003: Phylogeny and classification of the Digenea (Platyhelminthes: Trematoda). Int. J. Parasitol. 33: 733-755.

ORIAS J.D., NOBLE E.R., ALDERSON G.D. 1978: Parasitism in some east Atlantic bathypelagic fishes with a description of Lecithophyllum irelandeum sp. n. (Trematoda). J. Parasitol. 64: 49-51.

OVERSTREET R.M., PRITCHARD M.H. 1977: Two new zoogonid Digenea from deep-sea fishes in the Gulf of Panama. J. Parasitol. 63: 840-844.

PARUKHIN A.M. 1976: [Trematodes of fish in the Indian Ocean]. Biol. Morya, Kiev 38: 76-84. (In Russian.)

POWELL E.N., BARBER R.D., KENNICUTT M.C., FORD S.E. 1999: Influence of parasitism in controlling the health, reproduction and PHA body burden of petroleum seep mussels. Deep-Sea Res., Pt I. 46: 2053-2078.

REIMER L.W. 1985: Zwei neue Arten der Monorchiidae (Digenea) aus Fischen der Strasse von Moçambique. Angew. Parasitol. 26: 225-228.

SHIMAZU T., MACHIDA M. 1995: Some species of the genus Bivesicula (Digenea: Bivesiculidae), including three new species, from marine fishes of Japan and Palau. Bull. Nat. Sci. Mus., Tokyo, Ser. A. 21: 127-141.

TYLER P.A. 1995: Conditions for the existence of life at the deep-sea floor: an update. Oceanogr. Mar. Biol. 33: 221244.

WEITZMAN S.H. 1997: Systematics of deep-sea fishes. In: D.J. Randall and A.P. Farrell (Eds.), Deep-sea Fishes. Academic Press, San Diego, pp. 43-77.

ZUBCHENKO A.V. 1981: Parasitic fauna of some Macrouridae in the northwest Atlantic. J. Northwest Atl. Fish. Sci. 2: $67-72$.

ZUBCHENKO A.V. 1993: Vertical zones and formations of the parasitic fauna in deep-water fishes from the off-shore areas of the North Atlantic. In: V.K. Mitenev (Ed.), Parasitological studies of fish in the Northern Basin. Knipovich Polar Research Institute of Marine Fisheries and Oceanography (PINRO), Murmansk, pp. 39-60. (In Russian.)

Accepted 4 February 2004 